\title{
Fulminant Guillain-Barré syndrome in a patient with systemic lupus erythematosus
}

\author{
Eric Anthony Coomes, ${ }^{1}$ Hourmazd Haghbayan, ${ }^{1}$ Jenna Spring, ${ }^{2}$ Sangeeta Mehta ${ }^{2}$
}

'Department of Medicine, University of Toronto, Toronto, Ontario, Canada ${ }^{2}$ Interdepartmental Division of Critical Care Medicine, University of Toronto, Toronto, Ontario, Canada

\section{Correspondence to} Eric Anthony Coomes, eric.coomes@mail.utoronto.ca

Accepted 7 December 2018

Check for updates

(c) BMJ Publishing Group Limited 2019. No commercial re-use. See rights and permissions. Published by BMJ.

To cite: Coomes EA, Haghbayan H, Spring J, et al. BMJ Case Rep

2019:12:e226634.

doi:10.1136/bcr-2018-

226634

\section{SUMMARY}

A 45-year-old man with a history of systemic lupus erythematosus presented with progressive weakness and areflexia. Electromyogram revealed reduced motor and sensory amplitudes without demyelinating features. He was clinically diagnosed with the acute motor and sensory axonal neuropathy variant of GuillainBarré syndrome. Despite intravenous immunoglobulin therapy, he deteriorated with loss of all voluntary motor function and cranial nerve reflexes. Concomitant investigations revealed class $V$ lupus nephritis. Therapy was initiated with plasma exchange, glucocorticoids and further immunosuppression, with gradual neurological recovery. We present the first documented case of fulminant Guillain-Barré syndrome as a neuropsychiatric manifestation of systemic lupus erythematosus, highlighting how immune-mediated polyneuropathy via diffuse deafferentation may mimic the outward appearance of brain death. While glucocorticoids are not indicated in idiopathic Guillain-Barré, when this neurological disorder is a consequence of systemic lupus erythematosus, immunomodulatory treatment should be initiated to prevent neurological deterioration.

\section{BACKGROUND}

Guillain-Barré syndrome, or acute inflammatory polyradiculoneuropathy, is characterised by acute ascending progressive weakness, areflexia and dysautonomia. ${ }^{1}$ In its severest form, fulminant Guillain-Barré syndrome (GBS) may be mistaken for brain death with flaccid quadriplegia and absent brainstem reflexes due to effectively complete motor, sensory and autonomic denervation. The natural course of fulminant GBS is unknown, as only few reports exist in the literature. ${ }^{2}$ We present the first documented case of fulminant GBS as a neuropsychiatric manifestation of systemic lupus erythematosus (SLE), highlighting how immune-mediated polyneuropathy may mimic the outward manifestations of brain death.

\section{CASE PRESENTATION}

A 45-year-old man presented to hospital with new onset proximal upper and lower extremity weakness. His medical history was significant for SLE which was diagnosed 2 years prior following a presentation with polyarthritis, pericarditis, pleuritis, hypocomplementaemia and antinuclear and anti-Smith antibody positivity. $\mathrm{He}$ was well controlled on azathioprine $150 \mathrm{mg}$ and prednisone $5 \mathrm{mg}$ daily.
One week prior to presentation, he developed progressive shoulder girdle weakness, followed by distal paraesthesia, proximal lower extremity weakness and inability to ambulate. Neurological assessment revealed reduced power, with a Medical Research Council grade of severe in the deltoids [0/5] and biceps [2/5] symmetrically, and moderate [3-4/5] in all other muscle groups. Bicipital reflexes were absent.

\section{INVESTIGATIONS}

Routine biochemical investigations, including creatine kinase, were normal. Urinalysis revealed $1+$ protein without blood. C3 and C4 complement titres were depressed at 0.6 and $0.11 \mathrm{~g} / \mathrm{L}$, respectively, but unchanged from previous baseline values. Antibody testing redemonstrated positive antinuclear, anti-Smith, anti-RNP and anti-Ro antibody positivity.

Cerebrospinal fluid analysis was normal (white cell count $0 \times 10^{6} / \mathrm{L}, \quad \mathrm{RBC} 1 \times 10^{6} / \mathrm{L}$, protein $370 \mathrm{mg} / \mathrm{L}$ ); PCR testing was negative for West-Nile virus and herpesviruses. Serum HIV and syphilis tests were negative.

MRI of the brain and spine demonstrated cauda equina nerve root thickening and enhancement but no evidence of intracranial abnormalities. Electromyogram and nerve conduction studies revealed significant reductions in motor and sensory amplitudes without demyelinating features.

\section{DIFFERENTIAL DIAGNOSIS}

Given progressive upper and lower extremity weakness with areflexia and absence of cerebrospinal fluid pleocytosis, a clinical diagnosis of GBS was made. The electromyographic features of reduced motor and sensory amplitudes without features of demyelination supported the diagnosis of acute motor and sensory axonal neuropathy, a GBS variant.

\section{TREATMENT}

Intravenous immunoglobulin (IVIG, $2 \mathrm{~g} / \mathrm{kg}$ ) was administered. However, the patient's weakness progressed, culminating in quadriplegia and diffuse areflexia. Despite further IVIG, he deteriorated rapidly, developing facial paralysis and respiratory failure requiring endotracheal intubation and mechanical ventilation.

Three weeks following presentation, peripheral sensation diminished, and communication became limited to blinking. By 1 month, all voluntary 
Unusual presentation of more common disease/injury

Table 1 Reported cases of Guillain-Barré and Lupus

\begin{tabular}{|c|c|c|c|c|c|c|c|}
\hline Citation & $\begin{array}{l}\text { Age/ } \\
\text { gender }\end{array}$ & Timing & SLE features & Antibodies & GBS variant & Treatment & Outcome \\
\hline Chaudhuri et al ${ }^{6}$ & $40 \mathrm{M}$ & Concurrent & Seizure, class V nephritis, leucopenia & ANA, dsDNA & AIDP & $\begin{array}{l}\text { Plasma exchange, } \\
\text { steroid, CP }\end{array}$ & Partial: 16 wk \\
\hline Robson et $a l^{8}$ & $33 \mathrm{~F}$ & Concurrent & $\begin{array}{l}\text { Neuropsychiatric, vasculitis, haemolytic } \\
\text { anaemia, thrombocytopenia, lymphopenia, } \\
\text { complements }\end{array}$ & $\begin{array}{l}\text { ANA, dsDNA, } \\
\text { cardiolipin }\end{array}$ & AIDP & Steroid, CP & $\begin{array}{l}\text { Partial: } \\
8 \text { wk }\end{array}$ \\
\hline Matsuki et al ${ }^{20}$ & $61 \mathrm{~F}$ & Concurrent & $\begin{array}{l}\text { Arthralgia, pericardial effusion, anaemia, } \\
\text { leucopenia }\end{array}$ & $\begin{array}{l}\text { ANA, dsDNA, Ro, } \\
\text { La, GM1 }\end{array}$ & AMSAN & $\begin{array}{l}\text { Plasma exchange, } \\
\text { steroid, mizoribine }\end{array}$ & Partial: 8 wk \\
\hline Vaidya et al & $23 \mathrm{M}$ & Concurrent & Class V nephritis, complements & $\begin{array}{l}\text { ANA, dsDNA, } \\
\text { Smith }\end{array}$ & AIDP & $\begin{array}{l}\text { Plasma exchange, } \\
\mathrm{CP} \text {, steroid }\end{array}$ & Complete: undefined \\
\hline Miyagawa et al ${ }^{9}$ & $13 \mathrm{~F}$ & $\begin{array}{l}\text { SLE first } \\
\text { (6 years prior) }\end{array}$ & Chilblain, oral ulcers, leucopenia & $\begin{array}{l}\text { ANA, dsDNA, } \\
\text { Ro, La }\end{array}$ & AIDP & $\begin{array}{l}\text { Plasma exchange, } \\
\text { IVIG, steroid }\end{array}$ & Complete: 20 wk \\
\hline Stahl et al ${ }^{10}$ & $56 \mathrm{~F}$ & $\begin{array}{l}\text { SLE first } \\
\text { (1 year prior) }\end{array}$ & $\begin{array}{l}\text { Alopecia, arthritis, myelitis, oral ulcers, } \\
\text { anaemia, leucopenia, thrombocytopenia }\end{array}$ & $\begin{array}{l}\text { ANA, dsDNA, } \\
\text { histone }\end{array}$ & AIDP & $\begin{array}{l}\text { IVIG, steroid, CP, } \\
\text { plasma exchange, } \\
\text { CSF filtration }\end{array}$ & Complete: undefined \\
\hline $\begin{array}{l}\text { Van Laarhoven } \\
\text { et } a l^{23}\end{array}$ & $20 \mathrm{~F}$ & Concurrent & $\begin{array}{l}\text { Malar rash, pericardial/pleural effusions, } \\
\text { class IV nephritis, haemolytic anaemia, } \\
\text { complements }\end{array}$ & ANA, Smith, RNP & Unspecified & IVIG, CP, steroid & Complete: 24 wk \\
\hline Lewis and Gibson ${ }^{11}$ & $26 \mathrm{M}$ & $\begin{array}{l}\text { SLE first } \\
\text { (5years prior) }\end{array}$ & $\begin{array}{l}\text { Arthralgia, lymphadenopathy, myositis, } \\
\text { necrotizing vasculitis, pericardial/pleural } \\
\text { effusions, class I nephritis }\end{array}$ & $\begin{array}{l}\text { ANA, dsDNA, } \\
\text { Smith, RNP, } \\
\text { cardiolipin }\end{array}$ & AIDP & $\begin{array}{l}\text { IVIG, steroid, CP, } \\
\text { azathioprine }\end{array}$ & $\begin{array}{l}\text { Complete: } 10 \text { days. } \\
\text { * Recurred in } \\
8 \text { months, died }\end{array}$ \\
\hline Hsu et al ${ }^{12}$ & $28 \mathrm{~F}$ & Concurrent & Pleuritis, lymphopenia, complements & $\begin{array}{l}\text { ANA, dsDNA, } \\
\text { Ro, La }\end{array}$ & AIDP & $\begin{array}{l}\text { Plasma exchange, } \\
\text { steroid }\end{array}$ & Partial: 2 wk \\
\hline Yildiz et al ${ }^{13}$ & $47 \mathrm{~F}$ & $\begin{array}{l}\text { Concurrent } \\
\text { ( }{ }^{*} \text { history of } \\
\text { discoid lupus) }\end{array}$ & $\begin{array}{l}\text { Alopecia, oral ulcer, malar rash, anaemia, } \\
\text { leucopenia, thrombocytopenia }\end{array}$ & ANA & AMAN & Steroid, CP, HCQ & Partial: 12 wk \\
\hline $\begin{array}{l}\text { Rajadhyaksha and } \\
\text { Mehra }^{22}\end{array}$ & $30 \mathrm{~F}$ & Concurrent & $\begin{array}{l}\text { Arthralgia, oral ulcers, class II nephritis, } \\
\text { anaemia, complements }\end{array}$ & $\begin{array}{l}\text { ANA, dsDNA, } \\
\text { Smith, GT1a, } \\
\text { GQ1b, GM1b }\end{array}$ & $\begin{array}{l}\text { AMAN and } \\
\text { pharyngeal- } \\
\text { cervical- } \\
\text { brachial }\end{array}$ & IVIG, steroid, HCQ & Complete: 2 wk \\
\hline $\begin{array}{l}\text { Santiago-Casas } \\
\text { et al }\end{array}$ & $20 \mathrm{~F}$ & Concurrent & Lymphopenia, proteinuria & ANA, dsDNA & AMAN & $\begin{array}{l}\text { Plasma exchange, } \\
\text { IVIG, CP, steroid, } \\
\text { HCQ }\end{array}$ & Complete: 16 wk \\
\hline $\begin{array}{l}\text { Santiago-Casas } \\
\text { et al }{ }^{14}\end{array}$ & $34 \mathrm{~F}$ & $\begin{array}{l}\text { SLE first } \\
\text { (1 year prior) }\end{array}$ & Arthritis, lymphopenia & ANA, dsDNA & AMSAN & $\begin{array}{l}\text { IVIG, steroid, CP, } \\
\text { HCQ, azathioprine }\end{array}$ & Complete: 24 wk \\
\hline $\begin{array}{l}\text { Ha-ou-nou } \\
\text { et al } l^{15}\end{array}$ & $44 \mathrm{M}$ & Concurrent & $\begin{array}{l}\text { Malar rash, proteinuria, lymphopenia, } \\
\text { complements }\end{array}$ & ANA, dsDNA & AMAN & IVIG, steroid & Died \\
\hline Okoh et al ${ }^{21}$ & $41 \mathrm{~F}$ & Concurrent & $\begin{array}{l}\text { Pericardial/pleural effusions, class III/V } \\
\text { nephritis leucopenia, complements }\end{array}$ & $\begin{array}{l}\text { ANA, dsDNA, } \\
\text { Smith, GQ1 }\end{array}$ & Miller-Fisher & $\begin{array}{l}\text { Plasma exchange, } \\
\text { IVIG, steroid, CP, } \\
\text { MMF }\end{array}$ & Complete: 18 wk \\
\hline Fazio et $a l^{16}$ & $44 \mathrm{~F}$ & Concurrent & Lymphadenopathy & $\begin{array}{l}\text { ANA, dsDNA, } \\
\text { Smith, RNP, } \beta-2 \\
\text { glycoprotein }\end{array}$ & AIDP & IVIG, HCQ & Partial: undefined \\
\hline Nadri and Althaf ${ }^{17}$ & $23 \mathrm{~F}$ & Concurrent & Class V nephritis & ANA, dsDNA & AIDP & $\begin{array}{l}\text { Plasmapheresis, } \\
\text { IVIG, steroid, MMF }\end{array}$ & Partial: 24 wk \\
\hline Ali et $a l^{18}$ & $38 \mathrm{~F}$ & Concurrent & Oral ulcers, proteinuria, complements & $\begin{array}{l}\text { ANA, dsDNA, } \\
\text { Ro, lupus } \\
\text { anticoagulant }\end{array}$ & AIDP & $\begin{array}{l}\text { IVIG, steroid, CP, } \\
\text { HCQ }\end{array}$ & Partial: undefined \\
\hline Li and Wang $^{19}$ & $34 \mathrm{~F}$ & $\begin{array}{l}\text { SLE first } \\
\text { (3 years prior) }\end{array}$ & $\begin{array}{l}\text { Alopecia, arthritis, malar rash, oral ulcers, } \\
\text { class III nephritis, complements }\end{array}$ & $\begin{array}{l}\text { ANA, dsDNA, } \\
\text { Smith }\end{array}$ & AIDP & IVIG, steroid, CP & Partial: undefined \\
\hline Li and Wang $^{19}$ & $65 \mathrm{M}$ & Concurrent & $\begin{array}{l}\text { Arthralgia, class III nephritis, complements } \\
{ }^{*} \text { concomitant HCV diagnosis }\end{array}$ & $\begin{array}{l}\text { ANA, dsDNA, } \\
\text { ANCA }\end{array}$ & Unspecified & IVIG, steroid & Partial: 2 wk \\
\hline
\end{tabular}

AIDP, acute inflammatory demyelinating polyneuropathy; AMAN, acute motor axonal neuropathy; AMSAN, acute motor and sensory axonal neuropathy; ANA, antinuclear antibody; complements, hypocomplementaemia, CP, cyclophosphamide; CSF, cerebrospinal fluid; dsDNA, double-stranded DNA; GBS, Guillain-Barré syndrome; HCQ, hydroxychloroquine; IVIG, intravenous immunoglobulin; MMF, mycophenolate mofetil; RNP, ribonucleoprotein; SLE, systemic lupus erythematosus; wk, week; yr, year.

motor function was absent. Soon thereafter, reflex cranial nerve functions were lost including pupillary, corneal, vestibulo-ocular, cough and gag reflexes. Ventilator triggering and discernible autonomic response to painful stimuli were also absent, despite the absence of sedation or analgesia. At this stage, while the patient manifested the outward appearance of clinical brain death, a proximate cause of irreversible coma was absent; rather, diffuse deafferentation via profound peripheral nervous system damage was hypothesised to mimic a comatose state. Nevertheless, to definitively exclude central nervous system (CNS) injury, further testing was pursued. Repeat MRI demonstrated a structurally intact brain but now displayed decreased venous haemoglobin deoxygenation-a radiological finding typically observed in neuronal states of metabolic inactivity. Electroencephalography demonstrated unreactive stage-2 sleep, suggestive of a hypometabolic state, potentially 
on the basis of reduced CNS activity when devoid of peripheral stimulation.

Due to the severity of disease progression, plasma exchange was initiated. Initial clinical improvement soon followed, with gradual return of facial movements and communication via blinking. Concomitant surveillance investigations revealed a dramatic rise in proteinuria; repeat urinalysis demonstrated $4+$ protein and subsequent 24 hours urine collection identified $15.2 \mathrm{~g}$ of protein/24 hours. Renal biopsy confirmed class V lupus nephritis. Glucocorticoids were therefore initiated with a pulse of methylprednisolone $1 \mathrm{~g} /$ day for 3 days, followed by $1 \mathrm{mg} / \mathrm{kg}$ of prednisone daily in addition to mycophenolate mofetil.

\section{OUTCOME AND FOLLOW-UP}

Neurological recovery continued slowly, with return of sensation and increasing facial movements. After a protracted ventilator-dependent flaccid quadriplegia, he had gradual partial neurological recovery and after several months was successfully extubated. Given the chronicity of his clinical course, his diagnosis was revised to chronic inflammatory demyelinating polyneuropathy. His clinical recovery subsequently regressed, and he developed recurrent respiratory failure requiring reintubation. Intensified immunosuppression with rituximab B-cell depletive therapy was initiated. Over the following month, partial neurological recovery again occurred followed by successful extubation. With ongoing immunosuppression with rituximab, mycophenolate mofetil and corticosteroids in addition to intensive physiotherapy, the patient's strength and function continued to slowly recover.

\section{DISCUSSION}

GBS, or acute inflammatory polyradiculoneuropathy, is characterised by acute ascending progressive weakness, areflexia and dysautonomia. ${ }^{1}$ Involvement of the diaphragm and accessory respiratory muscles may necessitate ventilatory support. ${ }^{1}$ Several subtypes exist, including the classic acute inflammatory demyelinating polyneuropathy, and the rarer variant of acute motor sensory axonal neuropathy seen in this case. ${ }^{1}$ Albuminocytological dissociation (increased cerebrospinal fluid protein without pleocytosis) is seen in two-thirds of cases. ${ }^{1}$ Electrodiagnostic studies in demyelinating variants demonstrate decreased conduction velocity, prolonged latency and conduction blocks, whereas axonal forms display decreased motor and sensory amplitudes. Spinal imaging may reveal thickened and enhanced nerve roots and cauda equina, but cerebral imaging and electroencephalography should be unremarkable. ${ }^{1}$

The only proven therapies for GBS are IVIG and plasma exchange; previous meta-analyses indicate no benefit from corticosteroids. ${ }^{34}$ However, GBS is also recognised as a potential neuropsychiatric manifestation of SLE. ${ }^{5}$ Current guidelines indicate that when neuropsychiatric manifestations occur in the context of generalised SLE activity or when specific neurological manifestations reflect an underlying inflammatory process, such as peripheral neuropathy, pulse glucocorticoids should be used. ${ }^{5}$

Review of the literature reveals that cases of GBS in the context of SLE have predominantly presented with acute inflammatory demyelinating polyneuropathy followed by the acute motor axonal neuropathy variant. ${ }^{6-19}$ Rare cases of acute motor sensory axonal neuropathy, ${ }^{14}{ }^{20}$ Miller-Fisher syndrome ${ }^{21}$ and pharyngeal-cervical-brachial syndrome ${ }^{22}$ have also been reported. While standard GBS therapies such as plasma exchange and IVIG are often applied, in the majority of cases of concurrent SLE and GBS, additional immunosuppressive or immunomodulatory therapies have been employed, including corticosteroids, cyclophosphamide, azathioprine, ${ }^{14}$ mycophenolate mofetil ${ }^{17}$ and/or hydroxychloroquine. ${ }^{13} 14161822$ In some cases, patients did not respond to traditional GBS therapies, but had significant clinical improvement following immunosuppressive therapy. ${ }^{10}{ }^{14}$ Table 1 outlines previous cases of GBS complicating SLE, including patient demographics, SLE features, autoantibodies, GBS variant, treatment and outcomes.

Although GBS is not known to involve the CNS, our patient demonstrated a profound level of unconsciousness, with MRI and electroencephalographic findings hinting at an effective 'hibernation' of central neuronal metabolism. ${ }^{24}$ Was the unconsciousness in this patient mediated solely by their apparent complete peripheral nervous deafferentation? Such a theory would posit that external sensory input is a sine qua non for the maintenance of consciousness and is potentially supported by the patient's rapid return to consciousness once sensory input was restored with immunomodulatory therapy.

To our knowledge, this patient represents the first reported case of fulminant GBS mimicking brain death as a neuropsychiatric manifestation of SLE, with initial clinical response to sequential therapy with IVIG, plasma exchange and glucocorticoids. Contrasting with idiopathic GBS, the underlying pathophysiological process in this case may have been mediated by SLE activity and glucocorticoids may have altered the clinical course of the disease.

\section{Learning points}

- Fulminant Guillain-Barré syndrome may be a severe neuropsychiatric manifestation of systemic lupus erythematosus.

- Diffuse deafferentation from Guillain-Barré syndrome should be considered in the differential diagnosis for a patient with the outward manifestations of brain death.

- While glucocorticoids are not indicated in idiopathic GuillainBarré, in the context of systemic lupus erythematosus glucocorticoids and immunosuppressive treatment should be considered.

Acknowledgements The authors would like to thank Zareen Ahmad, M.D., M.SC., C.H., FRCPC; Jason Lazarou, M.D., M.SC., FRCPC; Christie Lee, M.D., M.SC., FRCPC and Michael Detsky, M.D., M.S.H.P., FRCPC for their valuable clinical insights and expertise in reviewing an early version of this manuscript.

Contributors EC, JS and SM cared for the patient. All authors contributed to the conception of the article. EC and HH drafted the manuscript. All authors revised the manuscript critically for important intellectual content.

Funding The authors have not declared a specific grant for this research from any funding agency in the public, commercial or not-for-profit sectors.

Competing interests None declared.

Patient consent Next of kin consent obtained.

Provenance and peer review Not commissioned; externally peer reviewed.

\section{REFERENCES}

1 Willison HJ, Jacobs BC, van Doorn PA. Guillain-Barré syndrome. Lancet 2016:388:717-27.

2 Ravikumar S, Poysophon P, Poblete R, et al. A case of acute motor axonal neuropathy mimicking brain death and review of the literature. Front Neurol 2016;7:63.

3 Hughes RA, Swan AV, van Doorn PA. Intravenous immunoglobulin for Guillain-Barre syndrome. Cochrane Database Syst Rev 2014;9:CD002063.

4 Hughes RA, Swan AV, van Koningsveld R, et al. Corticosteroids for Guillain-Barre syndrome. Cochrane Database Syst Rev 2006;2:CD001446.

5 Bertsias GK, loannidis JP, Aringer M, et al. EULAR recommendations for the management of systemic lupus erythematosus with neuropsychiatric manifestations: 
report of a task force of the EULAR standing committee for clinical affairs. Ann Rheum Dis 2010;69:2074-82.

6 Chaudhuri KR, Taylor IK, Niven RM, et al. A case of systemic lupus erythematosus presenting as Guillain-Barré syndrome. Br J Rheumatol 1989;28:440-2.

7 Vaidya S, Jasin HE, Logan J. Systemic lupus erythematosus and guillain-barre syndrome. J Clin Rheumatol 1999:5:349-53.

8 Robson MG, Walport MJ, Davies KA. Systemic lupus erythematosus and acute demyelinating polyneuropathy. Br J Rheumatol 1994;33:1074-7.

9 Miyagawa S, Nakajima M, Nishio K, et al. Guillain-Barré syndrome in a child with systemic lupus erythematosus and anti-Ro/SSA and anti-La/SSB autoantibodies. $\mathrm{Br} J$ Dermatol 2000;143:1050-4.

10 Stahl HD, Kalischewski P, Orda C, et al. Filtration of cerebrospinal fluid for acute demyelinating neuropathy in systemic lupus erythematosus. Clin Rheumatol 2000;19:61-3.

11 Lewis M, Gibson T. Systemic lupus erythematous with recurrent Guillain-Barré-like syndrome treated with intravenous immunoglobulins. Lupus 2003;12:857-9.

12 Hsu TY, Wang SH, Kuo CF, et al. Acute inflammatory demyelinating polyneuropathy as the initial presentation of lupus. Am J Emerg Med 2009;27:900.e3-900.e5.

13 Yildiz OK, Balaban H, Senel S, et al. Acute lumbosacral polyradiculoneuropathy heralding transformation to systemic lupus erythematosus in a patient with discoid lupus. Lupus 2011;20:972-4.

14 Santiago-Casas Y, Peredo RA, Vilá LM. Efficacy of low-dose intravenous cyclophosphamide in systemic lupus erythematosus presenting with Guillain-Barre syndrome-like acute axonal neuropathies: report of two cases. Lupus 2013;22:324-7.

15 Ha-ou-nou FZ, Dehbi S, Zahlane M, et al. [Acute polyradiculoneuropathy revealing systemic lupus erythematosus: an unusual presentation with fatal outcome]. Rev Med Interne 2014;35:65-7.
16 Fazio RM, Chen I, Somal N. Guillain-Barré syndrome as first presentation of systemic lupus erythematosus: a rare manifestation complicated by IVIg-induced splenic infarct. BMJ Case Rep 2015;2015:bcr2015211598.

17 Nadri Q, Althaf MM. Guillian-Barre syndrome as the initial presentation of systemic lupus erythematosus-case report and review of literature. Ann Saudi Med 2015:35:263-5.

18 Ali N, Rampure R, Malik F, et al. Guillain-Barré syndrome occurring synchronously with systemic lupus erythematosus as initial manifestation treated successfully with low-dose cyclophosphamide. J Community Hosp Intern Med Perspect 2016;6:30689.

19 Li X, Wang Y. Systemic Lupus Erythematosus With Acute Inflammatory Demyelinating Polyneuropathy: A Case Report and Review of the Literature. J Clin Med Res 2016;8:555-9.

20 Matsuki Y, Hidaka T, Matsumoto M, et al. Systemic lupus erythematosus demonstrating serum anti-GM1 antibody, with sudden onset of drop foot as the initial presentation. Intern Med 1999;38:729-32.

21 Okoh HC, Lubana SS, Langevin S, et al. A Case of Systemic Lupus Erythematosus Presenting as Guillain-Barré Syndrome. Case Rep Rheumatol 2015;2015:1-5.

22 Rajadhyaksha A, Mehra S. Pharyngeal-cervical-brachial variant of GuillainBarre syndrome with predominant bulbar palsy as the initial presentation of systemic lupus erythematosus and lupus nephritis: a case report. Int I Rheum Dis 2012;15:e162-e164.

23 van Laarhoven HWM, Rooyer FA, van Engelen BGM, et al. Guillain-Barré syndrome as presenting feature in a patient with lupus nephritis, with complete resolution after cyclophosphamide treatment. Nephrology Dialysis Transplantation 2001;16:840-2.

24 Laureys S, Owen AM, Schiff ND. Brain function in coma, vegetative state, and related disorders. Lancet Neurol 2004;3:537-46.

Copyright 2018 BMJ Publishing Group. All rights reserved. For permission to reuse any of this content visit https://www.bmj.com/company/products-services/rights-and-licensing/permissions/

BMJ Case Report Fellows may re-use this article for personal use and teaching without any further permission.

Become a Fellow of BMJ Case Reports today and you can:

- Submit as many cases as you like

- Enjoy fast sympathetic peer review and rapid publication of accepted articles

- Access all the published articles

- Re-use any of the published material for personal use and teaching without further permission

For information on Institutional Fellowships contact consortiasales@bmjgroup.com

Visit casereports.bmj.com for more articles like this and to become a Fellow 